\title{
Considering the Issue of Purpose in Leadership: A Review of Literature
}

\author{
By Megan Vercueil ${ }^{*} \&$ Angelo Nicolaides ${ }^{ \pm}$
}

\begin{abstract}
This article reviews and integrates the findings of academic leadership studies to guide leaders as they deal with practical implications of "purpose" in leadership at the workplace. This paper offers a theoretical analysis of trait, situational, and value-based leadership theory and presents a philosophically informed theoretical examination of purpose in leadership. Although there is great enthusiasm around the topic of purposeful leadership, much of the knowledge is based on qualitative studies rather than empirical evidence. We hope this article could usefully inform leadership by bringing academic knowledge to the fore to support the enterprise leadership environment. To date, limited empirical research on the role and importance of "purpose" in leadership is available. Our study fills this gap and is unique in that it analyses existing literature and proffers guidance irrespective of the leadership style of those towards whom it is directed.
\end{abstract}

Keywords: Leadership, individual, mission, organisation, purpose, values, vision.

\section{Introduction}

The process of enabling businesses to achieve significant results is entwined with notions of vision, mission, goals, objectives, and business plans, all of which imply that this process is related to purpose. ${ }^{1}$ According to Birkinshaw, Foss \& Lindenberg $^{2}$ purpose cannot be imposed through dictum, but is chosen by individuals. Basu and Palazzo hold the view that leadership studies have not framed purpose in the literature (work within the field of leadership has been characterised by rather simplistic commentaries on purpose), but rather, considerable attention has been paid to notions of purpose linked with business ethics and social responsibility. ${ }^{3}$

This article aims to share the findings of academic leadership studies to guide leaders as they deal with practical implications of "purpose" at work. Recognizing that leadership style can be affected by the purpose of the leader, the intention here is to proffer guidance irrespective of the current leadership style of those towards

\footnotetext{
* PhD, Graduate School of Business Leadership, University of South Africa / UNISA, South Africa; Head: Enterprise Moblity MTN (Pty) Ltd. Corresponding author.

E-mails:66256593@mylife.unisa.ac.za; megan.vercueil@mtn.com.

${ }^{ \pm}$Professor, Graduate School of Business Leadership, University of South Africa.

E-mail: pythagoras13@hotmail.com.

${ }^{1}$ Bass (1985).

${ }^{2}$ Birkinshaw, Foss \& Lindenberg (2014).

${ }^{3}$ Basu \& Palazzo (2008).
} 
whom it is directed. Further, the article acts as a foreground to the role of purpose within leadership studies.

\section{High-level Overview of Traditional Leadership Models}

Multiple aspects of leadership have been studied. It has been used as the subject for sociology, politics, psychology, pedagogy, ethics, and business, with much of the focus in each case being placed on the individual leader. ${ }^{4}$ Scottish Philosopher Thomas Carlyle looked, in 1840, at the distinctive innate qualities common among great leaders and believed that they were born and not made. This formed the basis of the Great-Man Theory. ${ }^{5}$ However, in 1948, Stogdill's research showed that there was no combination of traits that consistently differentiated leaders from non-leaders in different situations. ${ }^{6}$ Hersey and Blanchard developed a situational leadership framework that focused on enacting different management styles (based on the subordinates' maturity level) to enable competence and motivate staff and drive performance. ${ }^{7}$

In 1975, Dansereau et al. introduced the vertical dyad linkage theory, which dealt with the individual dyadic relationships formed between leaders and their subordinates; it has become more widely known as the leader-membership exchange (LMX) theory. ${ }^{8}$ Rost, based on the way leaders build high/low-quality exchange relationships with their subordinates (where the quality of such relationships depends on the level of trust, respect, and obligation between the manager and each subordinate), evolved the theory to more closely describe the relationship between the leader and his/her followers. ${ }^{9}$

Transformational theories focus on the connections between leaders and followers (Vision and Values which implies the "Whereto"). This concept was first introduced by James MacGregor Burns, and it arose from his studies of political leaders in 1978. ${ }^{10}$ House introduced charismatic leadership theories (included in transformational theory) that drew extensively upon the concept of vision, and these theories were further enhanced by Conger \& Kanungo and Shamir, House \& Arthur. ${ }^{11}$

Transformational leaders are characterised by extraordinary will and distinguish themselves by four main characteristics: charisma, inspirational motivation, intellectual stimulation, and individualised consideration. ${ }^{12}$ These theories focus on the connections formed between leaders and followers (Vision and Values, which implies the "Whereto"). ${ }^{13}$ Included in transformational theories

\footnotetext{
${ }^{4}$ Cardona (2019).

${ }^{5}$ Northouse (2019).

${ }^{6}$ Stogdill (1948).

${ }^{7}$ Hersey \& Blanchard (1969).

${ }^{8}$ Dansereau, Graen \& Haga (1975).

${ }^{9}$ Rost (1991).

${ }^{10}$ Northouse (2019).

${ }^{11}$ Conger \& Kanungo (1988); House (1977); and Shamir, House \& Arthure (1993).

${ }^{12}$ Bass \& Avolio (1994).

${ }^{13}$ Northouse (2019)
} 
are transactional theories, first described by Max Weber in 1947 and then by Bernard Bass in 1981. These theories focus on the role of supervision, organisation, and group performance (Goals, Plan, and Standards, which implies the "How"). ${ }^{14}$ Value-based theories include servant leadership, which originated in the writings of Greenleaf in 1970. Authentic leadership, popularised by Bill George in 2003, and adaptive leadership, was advanced in 2002 by Ron Heifetz and Marty Linsky in the book Leadership without Easy Answers. ${ }^{15}$ These theories emphasise the attention and concern of leaders towards followers. The leaders themselves are trustful and honest (authentic) and encourage people to deal with change (adaptive). ${ }^{16}$ They encapsulate purpose within the notion of "inspirational motivation." 17

\section{Defining Purpose}

According to Collins, purpose may be seen as an objective that guides action to achieve a goal in a particular context. ${ }^{18}$ To this extent, organisational vision and mission can be assimilated into purpose and interrelated with organisational leadership. $^{19}$

The idea of purpose being inherent in all beings was anchored by Aristotle within his ideas regarding teleology. ${ }^{20}$ Howie interprets Aristotle's notion of purpose not as simply having an idea of what is purposeful but also translating it into action. In the Merriam-Webster dictionary, purpose is defined as (i) noun: the reason for which something is done or created or for which something exists; a person's sense of resolve or determination; (ii) verb: have as one's intention or objective. ${ }^{21}$ MacIntyre also draws upon the Aristotelian philosophy (specifically the notion of telos, an ultimate object or aim) in that a person will feel fulfilled and gain a sense of well-being and purposefulness only if they move towards their telos. $^{22}$ The preceding philosophical definitions of purpose emphasise the notion of purpose as being a worthy idea and activity, the outcome of which is beyond the individual.

According to Craig and Snook, at an individual level, people may express their purpose in different ways in different contexts, but it is what others who know the individual well recognise as unique to the individual and would miss most if they were gone. ${ }^{23}$ At its core, leadership purpose springs from a person's identity - the essence of who they are - and must not be confused with their job, position, or title, or their education, experience, and skills. For the leader, it is

\footnotetext{
${ }^{14}$ Yukl (2013).

${ }^{15}$ Western (2019).

${ }^{16}$ DeRue, Nahrgang, Wellman \& Humphrey (2011); Northouse (2019); Western (2019).

${ }^{17}$ Bass (1985).

${ }^{18}$ Collins (2001).

${ }^{19}$ Kempster, Jackson \& Conroy (2011).

${ }^{20}$ Howie (1968).

${ }^{21}$ Merriam-Webster (2020).

${ }^{22}$ MacIntyre (2004).

${ }^{23}$ Craig \& Snook (2014).
} 
important that they intentionally identify their core, lifelong strengths, values, and passions, and pursuits that not only energise them but also bring them joy. ${ }^{24}$

Ladkin asserts that, to be congruent with one's purpose as a leader, one is required to attend to what one says, the way that one says it and also to ensure that it incorporates authenticity. ${ }^{25}$ In Carritt's collection of philosophical writings about beauty, he asserts that, "[to]Plato, beauty is not just truth or edification, beauty is not a physical thing, like gold, but rather some relation of things to our minds, perhaps to our purposes." ${ }^{26}$ This implies that to people, what is perceived as beautiful is connected to the mind and purpose. Leading is not just determined by position in a context, but also by the extent to which the leader acts in a way that "fits" his/her purpose. ${ }^{27}$ According to Craig, "Purpose is not a cause, a passion, an aspiration, or the sum of your values. Purpose is the unique gift that you bring to the world." 28

Murray states that perfect purpose is defined as an "overlap between doing something you love, the world needs, something you are great at, something you are paid for." "29 Alexandra and Douthit showed that determining "the why" in a business, establishes the drive of that organisation - its purpose is established with intention and is built on generating value internally for employees and externally for stakeholders and customers. ${ }^{30}$ Alvesson believes that used as a compass, purpose can provide a sense of direction to leaders and add to the DNA of the organisation. $^{31}$

\section{Purpose, Vision, and Mission}

According to the EY Beacon Institute, organisational purpose involves a vision that provides an aspirational reason for being grounded in humanity and inspires a call to action. ${ }^{32}$ Having an overarching purpose has been linked with meaningful work. It has been highlighted as the second most important factor for young people in the first five years of their career. ${ }^{33}$ According to Hill et al., organisational purpose should not be dismissed as cynical "fluffy nonsense" or, alternatively, monetised as the latest management fad, but rather it should be recognised as an essential approach to doing business and organizing work in the modern world. ${ }^{34}$

People often feel that they are in the same storm and working with others within the same company, yet they do not feel that they are in the same boat (or,

\footnotetext{
${ }^{24} \mathrm{Ibid}$.

${ }^{25}$ Ladkin (2008).

${ }^{26}$ Carritt (1931).

${ }^{27}$ Ladkin (2008).

${ }^{28}$ Craig (2018).

${ }^{29}$ Murray (2017).

${ }^{30}$ Alexandra \& Douthit (2016).

${ }^{31}$ Alvesson (2013).

${ }^{32}$ EY Beacon Institute (2016).

${ }^{33}$ Gusic (2015).

${ }^{34}$ Hill (2015).
} 
indeed, on the same page). According to Hutchison, organisational values become the foundation for mission development in that they are "the common strand running from a holistic understanding of the landscape, to mission statement formation and guidance of management." 35 The military defines leadership as influencing people by providing purpose, direction, and motivation, while operating to accomplish the mission and improve the organisation. ${ }^{36}$ For a team or a company, the mission concerns its members and cannot be imposed. ${ }^{37}$ Missions do not have bosses, but have leaders who do not necessarily fit within the chain of command. ${ }^{38}$ A sense (emotional and deeply personal feeling) of mission, according to Campbell and Yeung, can be defined as "an emotional commitment felt by people towards an organisation's mission" and occurs when there is a match between the values of an organisation and those of an individual. ${ }^{39}$

Stepping back to gain perspective is a practice as useful for organisations, as it is for individuals. ${ }^{40}$ According to Graham, in order for individuals and organisations to be the best versions of themselves, they need to have purpose, along with passion, possibilities (vision), and place. ${ }^{41}$ Jacobs and Longbotham found that processes such as seeking the counsel of trusted individuals, praying, and reflecting, helped establish a higher purpose in leaders and drove the desire to minimise any discrepancy between their spiritual beliefs and environmental conditions they found themselves in. ${ }^{42}$

Craig and Snook showed that not even $20 \%$ of leaders are aware of their own individual purpose. ${ }^{43}$ They showed that, while leaders may identify with their organisation' s purpose, they lack personal purpose. "Purpose is [...] the key to navigating the complex world we face today, where strategy is ever-changing, and few decisions are obviously right or wrong. If, therefore, we fail to identify our leadership purpose, we will be unable to develop and follow a plan to bring it into action and thereby achieve our most desired goals in both personal and professional regard."44 Most organisations have a profit-focused purpose, as individuals' purpose is not what we do, but rather how and why we do it. As a result, it is closely aligned with qualities such as awareness, respect, morality, vision, and understanding. ${ }^{45}$ In times of change, it is important for leaders, when conducting town halls and group conversations, to question what the organisation stands for as well as what it should continue or cease doing. ${ }^{46}$

Leadership studies have consistently acknowledged the essence of vision (the idealised verbal portrait of what an organisation aspires to achieve) as a significant

\footnotetext{
${ }^{35}$ Hutchinson (2011).

${ }^{36}$ Kolzow (2014).

${ }^{37}$ Drucker (1973).

${ }^{38}$ Malbašić, Rey \& Posarić (2018).

${ }^{39}$ Campbell \& Yeung (1991).

${ }^{40}$ Goleman \& Boyatzis (2017).

${ }^{41}$ Graham (2011).

${ }^{42}$ Jacobs \& Longbotham (2011).

${ }^{43}$ Craig \& Snook (2014).

${ }^{44}$ Ibid.

${ }^{45}$ Marques \& Dhiman (2017).

${ }^{46}$ O’Reilly \& Tushman (2013).
} 
component and determinant of leadership performance. ${ }^{47}$ Vision is future-oriented, an idealised utopia with a long-term time frame, and is crafted as a generalised, broad statement that can lend itself to multiple interpretations. ${ }^{48}$ Most studies on leadership have focused on how the vision is articulated and communicated. ${ }^{49}$ Strange and Mumford showed that the vision process arises from the leader's prescriptive mental model. ${ }^{50}$ Vision statements often make use of abstract language and imagery and emphasise values, distal goals, how to achieve them (which may be vague), and utopian outcomes. ${ }^{51}$ Boisot and McKelvey hold that, to be effective, organisations need to have adaptive systems where the complexity of their business can match that of the environment. ${ }^{52}$

According to Erçetin et al., order can emerge from chaos and that natural systems have the ability to self-organise. ${ }^{53}$ Natural systems show us that "strange attractors" in chaos bring order, as seen, for example, in snowflakes. ${ }^{54}$ In today's competitive and globalised world, more companies rely on intellectual capital rather than production activities. These evolving organisations deeply embrace innovation, knowledge, technology, learning, and adaptation as core competencies. ${ }^{55}$ In addition, they have to constantly adapt and change (to survive) to environmental changes and an increasingly complex world through innovation and continuous learning. ${ }^{56}$ Kahane identified three complexities at the root of the toughest problems leaders face today: "(i) dynamic complexity: cause and effect distant in time and space; (ii) social complexity: diverse stakeholders with different agendas and worldviews; and (iii) generative complexity: emergent realities wherein solutions from the past no longer fit." ${ }^{, 57}$ A realistic view of current leadership demands and the contextual environment must incorporate the complexities involved in developing an effective vision. ${ }^{58}$

Due to environmental dynamics, organisational actors are constantly changing. Leadership tenure in modern organisations is often short-lived because of competing institutional challenges, demands for agile leadership competence, and low tolerance for failure among stakeholders. ${ }^{59}$ A central question is whether vision is relevant, or even necessary, given the complexities and dynamics of the environment and the need for constant adaptation. ${ }^{60}$ To be effective, a vision requires the leader to have an understanding of the past, have deep knowledge of the present, and the capacity to use available information to make accurate

\footnotetext{
${ }^{47}$ Rafferty \& Griffin (2004).

${ }^{48}$ Marques \& Dhiman (2017).

${ }^{49}$ Carton, Murphy \& Clark (2014); Venus, Stam \& van Knippenberg (2013).

${ }^{50}$ Strange \& Mumford (2002).

${ }^{51}$ Berson, Halevy, Shamir, \& Erez (2015).

${ }^{52}$ Boisot \& McKelvey (2010).

${ }^{53}$ Erçetin, Açikalin, \& Bülbül (2013).

${ }^{54}$ Ibid.

${ }^{55}$ Marques \& Dhiman (2017).

${ }^{56}$ Hahn, Pinkse, Preuss,\& Figge (2015).

${ }^{57}$ Kahane (2004).

${ }^{58}$ Marques \& Dhiman (2017).

${ }^{59}$ Treviño \& Nelson (2017).

${ }^{60}$ Marques \& Dhiman (2017).
} 
projections of future events. ${ }^{61}$ Working with other neuroscientists, Zimmer conducted a study on mental time travel and found that individuals use the same region of their brain to both, remember the past and envision the future. ${ }^{62}$ Zimmer concluded that episodic memories of the past are crucial to predicting the future.

In many organisations, mission and vision statements eventually tend to be forgotten. ${ }^{63}$ Vision requires not only thoughtful planning but also intention. ${ }^{64}$ Intention is also closely tied to one's sense of purpose. ${ }^{65}$ Meaningful purpose creates much stronger intention, and the vision keeps the purpose alive and vivid with anticipatory images of the future. ${ }^{66}$ Collins, in his best-seller Good to Great, observes that one of the reasons some companies manage to maintain an outstanding performance over a long period compared to their competitors is that they have an enduring sense of purpose. ${ }^{67} \mathrm{He}$ notes that having such sense of purpose breeds a clear sense of direction and in turn, aids prioritization and inspires people to go the extra mile. Furthermore, he concludes from his five years of research, that the very best leaders (Level V, as he refers to them) possess two competencies: (i) a resolute and unflinching focus on the purpose of the organisation coupled with; and (ii) a deep sense of humility.

\section{Integrating Purpose and Leadership}

At an individual level, a person discovers and defines their personal mission. They are the only one who can fully assess its scope and meaning. ${ }^{68}$ From a neuroscience perspective, having a sense of purpose and belonging, being respected, and feeling worthy changes our brain chemistry and fosters positivity in the way people approach life and the challenges facing them. ${ }^{69}$ Having a personal mission drives higher performance, enhances the use of existing capabilities, and creates new skills. ${ }^{70}$ According to Dhang, many individuals lack clarity of direction and clarity of what they want to achieve. Most people live and die like that." ${ }^{, 71}$ At the leadership level, according to Craig and Snook, despite the interest in purposeful leadership, few leaders have a clear sense of their own purpose and many are unable to distill this down to a specific statement of purpose or an action plan. $^{72}$ This raises the question of how someone without a personal mission can define a mission for someone else. ${ }^{73}$

\footnotetext{
${ }^{61}$ O’Reilly \& Tushman (2013).

${ }^{62}$ Zimmer (2011).

${ }^{63}$ Marques \& Dhiman (2017).

${ }^{64}$ Taiwo, Lawal, \& Agwu (2016).

${ }^{65}$ Graham (2011).

${ }^{66}$ Marques \& Dhiman (2017).

${ }^{67}$ Collins (2011).

${ }^{68}$ Christensen (2010).

${ }^{69}$ Murray (2017).

${ }^{70}$ Grant (2008); Craig \& Snook (2014).

${ }^{71}$ Dhang (2012).

${ }^{72}$ Craig \& Snook (2014).

${ }^{73}$ Malbašić, Rey \& Posarić (2018).
} 
Smircich and Morgan argue that leadership involves a process of defining reality in ways that resonate with followers. ${ }^{74}$ They present a process comprising three phases through which leaders create meaning for followers. Phase 1 includes framing and shaping context-isolating an element of experience within the context in which it is set; phase 2 involves interpreting the significance of the issue; and phase 3 grounds the subsequent action within the interpretation of the meaning of that action. ${ }^{75}$ They further argue that leaders have dual conflicting roles that involve maintaining institutionalised order and structures, and having also to rise above the formal structures to provide meaning and direction. ${ }^{76}$

According to Dhang, personal and organisational missions have several common characteristics: (i) both must be concise, clear, and informative; and (ii) a personal mission statement should cover the same three areas - purpose, activities, and values - as an organisational mission statement. ${ }^{77}$ It is important to note, as pointed out by Ramsey, that mission statements do not contain specific time frames, benchmarks, or yardsticks, but rather are overarching blueprints for everyday life and work. ${ }^{78}$ Christensen holds the view that people should decide what they stand for and then stand for it all the time. ${ }^{79}$

Kotter exhorts leaders to influence their followers to unite toward a shared vision (or purpose) ${ }^{80}$ Pye argues that leadership can be productively seen as a process of framing and managing meaning. ${ }^{81}$ Carton et al. believe that the most central of all leadership behaviours is to communicate purpose to align the organisation around an envisaged cause or dream. ${ }^{82}$ Although alignment has been considered key to attaining extraordinary performance in the past, new studies have found that it may no longer be the right approach to succeed in the creation of a common purpose. According to Mayfield, purposeful leadership combines different factors, such as vision, inspiration, direction, action-orientation, critical thinking, morality, values and ethics. ${ }^{83}$

Purposeful organisations that consider the needs of multiple stakeholders are presumed to be capable of generating higher levels of performance and more valuable innovations as well as improving employee motivation and engagement. ${ }^{84}$ Birkinshaw et al. showed it is not merely about communicating the firm's purpose, but rather discovering (and rediscovering) the pre-existing shared purpose. ${ }^{85}$ As it relates to influence, it is not in the hands of one (the leader), but in the hands of all who share the purpose and who are thus eager to bring it to life in their work. The result is an authentic commitment by employees to fulfil their responsibilities with

\footnotetext{
${ }^{74}$ Smircich \& Morgan (1982).

${ }^{75}$ Ibid.

${ }^{76}$ Ibid.

${ }^{77}$ Dhang (2012).

${ }^{78}$ Ramsey (2003).

${ }^{79}$ Christensen (2010).

${ }^{80}$ Kotter (1996).

${ }^{81}$ Pye (2005).

${ }^{82}$ Carton, Murphy \& Clark (2014).

${ }^{83}$ Mayfield (2013).

${ }^{84}$ Wilson (2015).

${ }^{85}$ Birkinshaw, Foss \& Lindenberg (2014).
} 
a sense of honour and obligation that arises only from a fully internalised understanding of the shared purpose. ${ }^{86}$

Cardona and Rey noted three ways in which the personal mission is related to, but remains different from, the organisational mission: (i) organisational mission is not the personal mission (personal mission will have goals more specific than those of organisational mission); (ii) organisational mission does not override the personal mission (people can get caught up in their work life, sometimes forgetting their personal life, and behave as if serving the company were their sole purpose in life) and (iii) organisational mission and personal mission must be complementary (staff at a company have the sense that their daily work acquires a genuine sense of contribution and self-realization). ${ }^{87}$

Given the amount of time spent at work, the workplace has become a source of meaning for individuals. ${ }^{88}$ The context for employee engagement is embedded in the culture of an organisation, and the culture is the vehicle into which purpose is embedded. ${ }^{89}$ According to Schein, it is by understanding our culture that we can understand ourselves and the forces acting upon us that define us. ${ }^{90}$ Culture is identified as the "strongest competitive difference" a company has. Honeyman found that there is an increasing trend that asks businesses and leaders to strive for more. ${ }^{91}$ Deloitte postulated that putting an emphasis on purpose rather than profits generates confidence, drives investment and creates long-term success. ${ }^{92}$

Motivation theorists and humanistic psychologists have supported the notion that individuals have an inherent need for meaningful work. ${ }^{93}$ People are looking for meaning in life and if they can find that in their work and the companies they work for, it unleashes a powerful motivator that companies are beginning to understand. In addition, from a societal perspective, it is becoming increasingly difficult to separate profit from purpose. ${ }^{94}$

\section{Connecting Organisational Purpose and Individual Purpose}

In general, vision, mission, and objectives are oriented to corporate purposes that deliver external expectations. ${ }^{95}$ Drath and Palus argue that leadership is more than a person - it is a sense of purpose, a force that gives people a common direction and place with an increasing emphasis upon systemic relationships and mutual meaning-making. ${ }^{96}$ According to Kempster et al., there is a tendency for

\footnotetext{
${ }^{86}$ Ibid.

${ }^{87}$ Cardona \& Rey (2009).

${ }^{88}$ Alexander \& Douthit (2016).

${ }^{89}$ Ibid.

${ }^{90}$ Schein (201).

${ }^{91}$ Honeyman (2014).

${ }^{92}$ Deloitte (2014).

${ }^{93}$ Alderfer (1972); Herzberg, Mausner \& Snyderman (1959); McClelland (1965); McGregor (1960).

${ }^{94}$ Lin (2010); Deloitte (2014).

${ }^{95}$ Kempster, Jackson \& Conroy (2011).

${ }^{96}$ Drath \& Palus (1994).
} 
purpose within business and the public sector to become overly preoccupied with the outputs of external goods such as profit, shareholder return, and value for money, or efficiencies. ${ }^{97}$ Cardona et al. found that leaders who are willing to support people, within their organisations, in the development of their purpose, receive more help in return while driving organisational needs. ${ }^{98}$ Organisational purposes that go beyond a mere focus on the bottom line have fuelled interest in understanding the growing disillusionment with the short-term financial imperatives that are blamed for the collapse of leadership integrity. ${ }^{99}$ Gusic holds the view that leaders play a significant role in helping organisations realise their purpose. ${ }^{100}$

According to Cardona and Rey, it is precisely at the junction of both the company mission and personal mission that role mission is configured. For an individual, role mission reveals what their personal mission brings to the company mission and vice versa. ${ }^{101}$ This contribution characterises the identity of each person in their professional role. ${ }^{102}$ Once the role mission is part of the company mission, it is also common to both the company mission and the individual mission. It is not a simple exercise in "self-awareness" disconnected from the company mission, nor is it an exercise in indoctrination of the corporate mission without regard for personal mission. Both extremes generate disappointment, lack of authenticity, and loss of work motivation. Hence, it is in the individual's "interest" that the company has a mission, just as it is in the company's "interest"' that the individual has a life mission. ${ }^{103}$

Empirical research shows that meaningful work affects employee commitment, job satisfaction, engagement and work performance. ${ }^{104}$ Individuals with a sense of purpose have an emotional attachment and commitment to a company, what it stands for, and what it is trying to do. ${ }^{105}$ A company with a clear and strong mission statement does not necessarily translate into its employees having an emotional commitment to that mission statement. ${ }^{106}$

Erickson theorised that young adults (millennials) are focused on building relationships and when they reach middle age, there is a shift to associate identity with what one is contributing to society. ${ }^{107}$ According to Campbell and Yeung, "people are too varied and have too many individual values for it to be possible for a large organisation to achieve a values match for all its employees." ${ }^{108}$ That said,

\footnotetext{
${ }^{97}$ Kempster, Jackson \& Conroy (2011).

${ }^{98}$ Cardona, Rey \& Craig (2019).

${ }^{99}$ Bailey, Madden, Alfes \& Fletcher (2017).

${ }^{100}$ Gusic (2015).

${ }^{101}$ Cardona \& Rey (2008).

${ }^{102}$ Cardona \& Rey (2008).

${ }^{103}$ Malbašić, Rey \& Posarić (2018).

${ }^{104}$ Steger, Dik \& Duffy (2012); Steger, Littman-Ovadia, Miller \& Menger (2013).

${ }^{105}$ Campbell \& Yeung (1991).

${ }^{106}$ Malbašić, Rey \& Posarić (2018).

${ }^{107}$ Erickson (1994).

${ }^{108}$ Campbell \& Yeung (1991).
} 
leaders need to lead by example, conscious of the fact that their colleagues' mission depends, in part, on how they live their own. ${ }^{109}$

\section{Impact of Purpose on Organisational Performance}

While many companies understand that having a stated purpose is important, they struggle to weave it into day-to-day business. ${ }^{110}$ The EY Beacon Institute undertook research in 2018 to understand whether company purpose had any longterm financial performance effect. ${ }^{111}$ Their study covered 1,470 business leaders across 12 locations (Australia, the United Kingdom, the United States, China, India, Brazil, Japan, Singapore, Hong Kong SAR, South Africa, France, and Germany) and 10 industries (automotive and transportation, banking and capital markets, consumer products and retail, diversified industrial products, government and public sector, health, life sciences, mining and metals, oil and gas, and professional services). The findings showed that strong and active purpose raised employee engagement and acted as a unifier, supported more loyal and committed customers, and helped frame effective decision making for leaders in an environment of uncertainty. ${ }^{112}$

Figure 1. Impact of Purpose on Organisational Financial Performance

\section{Three levels of purpose and impact on financial performance}

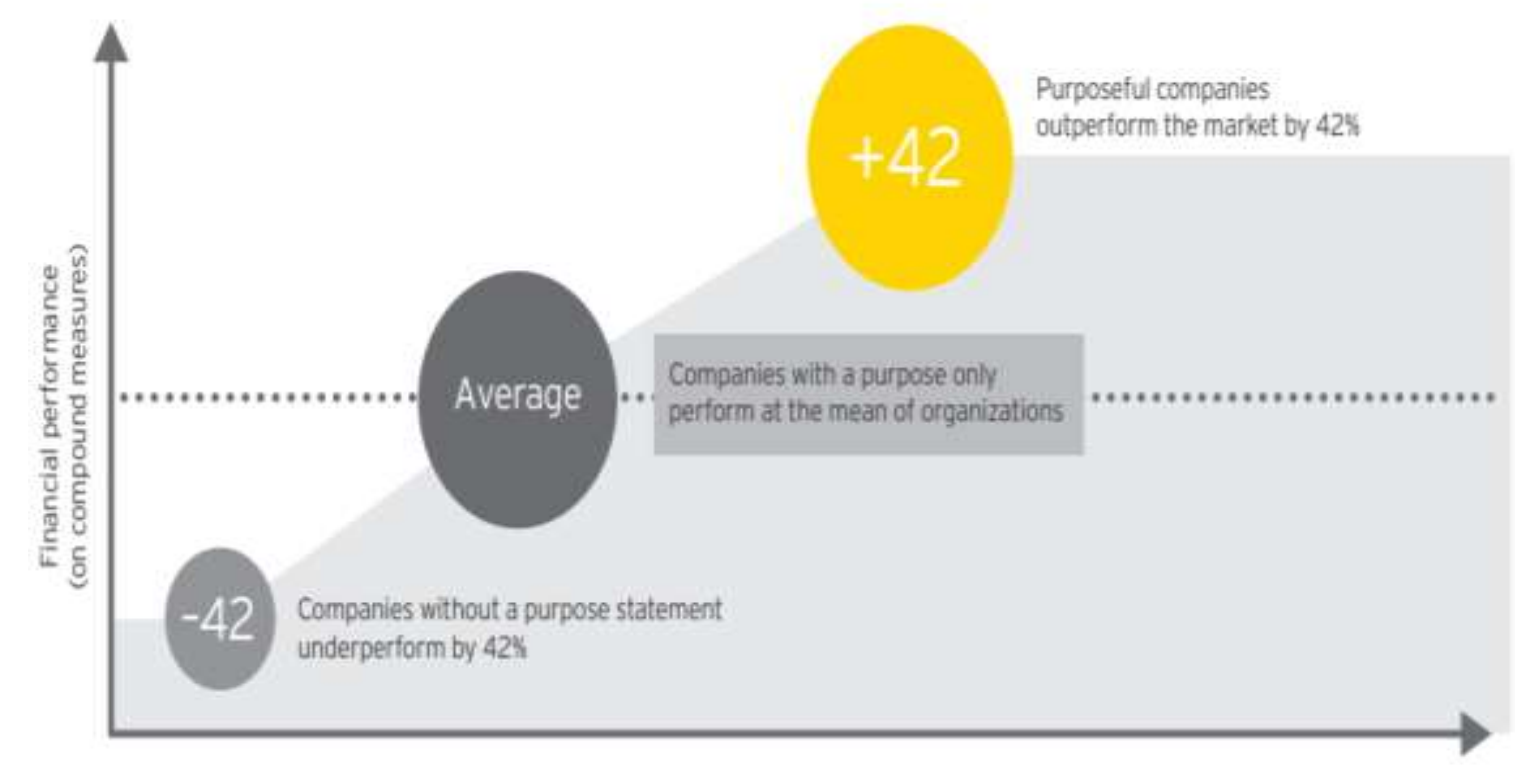

Source: Global Leadership Forecast released by DDI, The Conference Board, and EY (2018)

\footnotetext{
${ }^{109}$ Marimon, Mas-Machuca \& Rey (2016).

${ }^{110}$ Quinn \& Thakor (2018).

${ }^{111}$ EY Beacon Institute (2018).

${ }^{112}$ Beacon Institute (2018).
} 
Of the 1,470 global C-Suite executives surveyed, 84 per cent believed that their business operated in an increasingly disrupted environment and likened purpose to a fixed point to help navigate change and uncertainty. ${ }^{113}$ The findings further showed that purposeful organisations (those with the support of active leadership who authentically demonstrated their values and company purposeliving, breathing and effectively demonstrating a commitment to that purpose is an infinitely larger task than paying lip service in this regard) had a stronger financial performance in the short and long term than companies where only a purpose statement was written up but not enacted. They were also better equipped to deal with fast-changing, competitive environments. The Global Leadership Forecast 2018 showed that "living a purpose statement at work not only had a positive effect on engagement (engagement levels were 12 per cent and employees' intent to stay 14 per cent higher), but twice as many leaders found meaning from the work they were doing.

The changing economic landscape has prompted a fundamental rethink within many companies about the how and why of their business. Purpose is personal at an individual level and, at the company level, needs to be embedded into the goals, strategies, objectives, governance, and decision-making processes and systems. ${ }^{114}$

Figure 2. How Purpose Creates Value

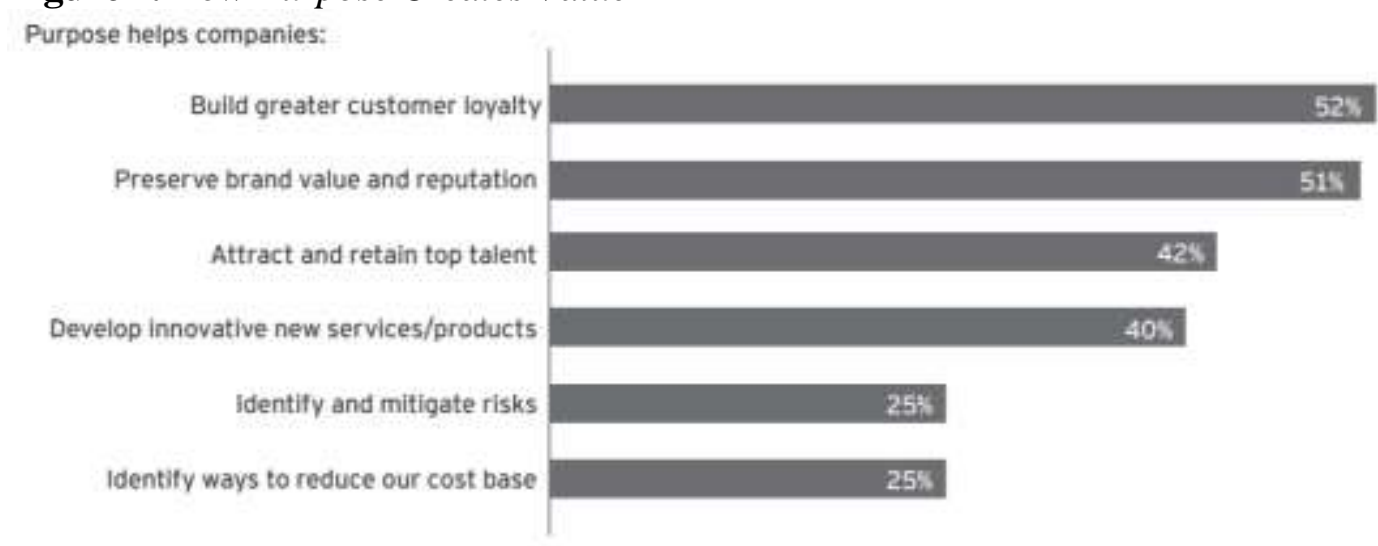

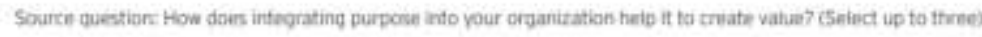

Source: Global Leadership Forecast released by DDI, The Conference Board, and EY (2018)

Implementing purpose within an organisation's way of work faces a number of barriers such as short-term shareholder pressure, systems, and infrastructure that are not aligned with long-term purpose and the perceived cost for employees who seek to minimise personal cost and effort. ${ }^{115}$ Purpose aligns people toward something more significant than shareholder returns. ${ }^{116}$ However, according to Quinn and Thakor, leaders need to choose between stricter controls (employees choose to respond primarily to the incentives outlined in their contracts and the

\footnotetext{
${ }^{113}$ Beacon Institute (2018).

${ }^{114}$ Quinn \& Thakor (2018).

${ }^{115}$ EY Beacon Institute (2018); Quinn \& Thakor (2018).

${ }^{116}$ Bailey, Madden, Alfes \& Fletcher (2017).
} 
controls imposed on them to achieve the desired impact) or aligning the organisation with an authentic higher purpose that intersects business interests and goals and helps guide decisions across all levels. ${ }^{117}$

\section{Conclusion}

People need leadership for personal fulfilment and to reach their full potential. ${ }^{118}$ It is often during a crisis where leaders are forced to challenge their assumptions about motivation and performance and to experiment with new approaches. ${ }^{119}$ When leaders connect their own purpose to organisational purposes, their influence intensifies. ${ }^{120}$ In the current changing world, where the way forward appears increasingly blurred and it is more difficult to determine whether a decision is right or wrong, leaders' life missions play a critical role in guiding and leading over time, as does the need for organisations to be more human in an ever-increasing digital age. ${ }^{121}$

Mission and values are inextricably linked, and discussions of leadership for the "new normal" often implicitly assume that we all share the same old normal. An employee's personal mission, manifested through purposeful work, affects important elements of organisational behaviour and business performance. The role of values in determining purpose, vision, and mission is vital, as values are the "glue" that hold personal and organisational purposes together. ${ }^{122}$ Serving all stakeholders, and aspiring to improve society, gives a company a broader vision, making it more likely to spot unexpected opportunities and new risks that are emblematic of disruptive and volatile times. ${ }^{123}$

Leading translates possibilities into realities and purpose is crucial in each moment as part of how leaders interact and address challenges. In the face of tough realities for organisations, everyone associated needs to be open to being a leader. The purpose is not genetic and no person is born with a predetermined work orientation - even the world's most successful leaders have secrets in their journey to success and achieving their purpose. ${ }^{124}$ Leading requires courage and the understanding of where managers' responsibility ends and responsibility as leaders begins - providing purpose is a leader's role and leadership is a major intangible asset to a business.

According to Professor Michael Beer of Harvard Business School, "It is essential that companies develop the kind of leaders that can communicate and align the whole organisation around purpose. A leader's ability to influence people

\footnotetext{
${ }^{117}$ Quinn \& Thakor (2018).

${ }^{118}$ Cardona, Rey \& Craig (2019).

${ }^{119}$ Quinn \& Thakor (2018).

${ }^{120}$ Cardona, Rey \& Craig (2019).

${ }^{121}$ Craig \& Snook (2014).

${ }^{122}$ Malbašić, Rey \& Posarić (2018).

${ }^{123}$ Beacon Institute (2018).

${ }^{124}$ Dweck (2016).
} 
to act does not necessarily come from the position they hold but rather from a strong belief in a purpose and willingness to pursue that conviction."125

Organisations are political systems on their own and it should not be too difficult to state a purpose and a set of values. ${ }^{126}$ When a company announces its purpose and values and they are not reflected by the behaviour of senior leadership, those words ring hollow. ${ }^{127}$ It is much harder to enact purpose in the organisation because it requires leaders to continually search for multi-disciplinary consistency. ${ }^{128}$ According to Kolzow, "[u]nless leaders understand the vision that motivates them to lead, the purpose that inspires them, and the values that empower them, it is difficult to make courageous and necessary choices and decisions in a chaotic world." 129

A review of the available literature shows that there is a great amount of enthusiasm around the topic of purposeful leadership. However, much of this is based on qualitative studies rather than empirical evidence, and further research is needed to substantiate this notion of the importance and impact of purpose in terms of leadership and its desired outcomes.

\section{References}

Alderfer, C.P. (1972). Existence, Relatedness and Growth: Human Needs in Organisational Settings. New York, NY.: Free Press.

Alexander, A.K. \& M.W. Douthit (2016). 'The Power of Purpose: How Organisations are making work more meaningful' in Academy of Management Proceedings 2016(1). DOI:10.5465/ambpp.2016.11489abstract.

Alvesson, M. (2013). Understanding Organisational Culture, 2nd ed. Thousand Oaks, Ca.: SAGE Publications.

Bailey, C., Madden, A., Alfes, A. \& L Fletcher (2017). 'The Meaning, Antecedents and Outcomes of Employee Engagement: A Narrative Synthesis' in International Journal of Management Reviews 19(1):31-53.

Bass, B.M. (1985). Leadership and performance beyond expectations. New York, N.Y.: Free Press.

Bass, B.M. \& B.J. Avolio (1994). Improving Organisational Effectiveness Through Transformational Leadership. Thousand Oaks, Ca.: SAGE.

Basu, K. \& G. Palazzo (2008). 'Corporate social responsibility: A process model of sensemaking' in Academy of Management Review 33(1):122-136.

Berson, Y., Halevy, N., Shamir, B. \& M. Erez (2015). 'Leading From Different Psychological Distances: A Construal-Level Perspective on Vision Communication, Goal Setting, and Follower Motivation' in The Leadership Quarterly 2(2):143-155.

Birkinshaw, J., Foss, N.J. \& S. Lindenberg (2014). 'Combining purpose with profits' in MIT Sloan Management Review (55)3:49.

\footnotetext{
${ }^{125}$ Botelho, Powell, Kincaid \& Wang (2017).

${ }^{126}$ Dweck (2016); Rousmaniere (2015).

${ }^{127}$ Quinn \& Thakor (2018).

${ }^{128}$ Ibid.

${ }^{129}$ Kolzow (2014).
} 
Boisot, M. \& B. McKelvey (2010). 'Integrating modernist and postmodernist perspectives on organisations: A complexity science bridge' in Academy of Management Review 35(3):415-433.

Botelho, E.L., Powell, K.R., Kincaid, S. \& D. Wang (2017). What sets successful CEOs apart. https://hbr.org/2017/05/what-sets-successful-ceos-apart. .

Campbell, A. \& S. Yeung (1991). 'Creating a sense of mission' in Long Range Planning 24(4):10-20.

Cardona, P. \& C. Rey (2008). Management by Missions. Basingstoke: Palgrave Macmillan.

Cardona, P., Rey, C. \& N. Craig (2019). 'Purpose-driven leadership' in Rey, C., Bastons, M., Sotok, P. (eds). Purpose-Driven Organisations, pp. 29-41, Palgrave Macmillan, Cham,. Switzerland: Palgrave Macmillan.

Carritt, E.F. (1931). Philosophies of Beauty: From Socrates to Robert Bridges, Oxford: Clarendon Press.

Carton, A.M., Murphy, C. \& J.R. Clark (2014). 'A (blurry) vision of the future: How leader rhetoric about ultimate goals influences performance' in Academy of Management Journal 57(6):1544-1570.

Christensen, C.M. (2010). 'How will you measure your life?' in Harvard Business Review $88(7-8): 46-51$.

Collins, J. (2001). Good to Great. New York: HarperCollins, Inc.

Conger, J.A. \& Kanungo, R.N. (1988). Charismatic Leadership: The Elusive Factor in Organisational Effectiveness. San Francisco, Ca.: Jossey-Bass.

Craig, N. (2018). Leading From Purpose: Clarity and Confidence to Act When It Matters. New York., N.Y.: Hachette Book Group Inc.

Craig, N. \& S.A. Snook (2014). 'From purpose to impact: Figure out your passion and put it to work' in Harvard Business Review 92(5):105-111.

Dansereau, F., Graen, G.G. \& W.J. Haga (1975). 'A vertical dyad linkage approach to leadership in formal organisations' in Organisational Behavior and Human Performance 13(1):46-78.

Deloitte (2014). Culture of purpose - Building business confidence; driving growth 2014 ore beliefs \& culture. survey. https://www2.deloitte.com/content/dam/Deloitte/us/ Documents/about-deloitte/us-leadership-2014-core-beliefs-culture-survey040414.pdf

DeRue, D.S., Nahrgang, J.D., Wellman, N. \& S.E. Humphrey (2011). 'Trait and behavioural theories of leadership: An integration and meta-analytic test of their relative validity'in Personnel Psychology 6(1):7-52.

Dhang, S. (2012). 'The role of teachers in nation-building' in DYPIMS's International Journal of Management and Research 1(1):53-59.

Drath, W. H., \& C.J. Palus (1994). Making common sense: Leadership as meaningmaking in a community of practice (Technical Report No. 156). Greensboro, NC: Center for Creative Leadership.

Drucker, P.F. (1973). Management: Tasks, Responsibilities, Practices. New York, N.Y.: Harper Business.

Dweck, C. (2016). Mindset, the New Psychology of Success. New York: N.Y.: Ballentine Books.

Erçetin, Ş.Ş., Açikalin, S.N. \& M.S. Bülbül (2013). 'A multi-dimensional approach to leadership in chaotic environments' in Advances in Business Strategy and Competitive Advantage. IGI Global, pp. 89-104.

Erikson, E.H. (1994). Identity: Youth and Crisis (No. 7). WW Norton \& Company.

EY Beacon Institute (2016) The state of the debate on purpose in business EYGM Ltd. http://www.ey.com/Publication/vwLUAssets/EY-pursuit-of-purpose-exec-sum/\$FI LE/EYpursuit-of-purpose-exec-sum.pdf 
Vol. 7, No. $3 \quad$ Vercueil \& Nicolaides: Considering the Issue of Purpose in Leadership...

Boyatzis, R., Boyatzis, R.E. \& D. Goleman (2017). 'Emotional Intelligence as 12 Elements. Which do you need to work on?' Harvard Business Review https://hbr.org/ 2017/02/emotional-intelligence-has-12-elements-which-do-you-need-to-work-on

Graham, K. (2011). 'Leading with purpose: A case for soul leadership' in Development and Learning in Organisations: An International Journal 25(4):5-7.

Grant, A.M. (2008). 'The significance of task significance: Job performance effects, relational mechanisms, and boundary conditions' in Journal of Applied Psychology 93(1):108-124.

Gusic, I. (2015). The value of purpose-driven leaders [Blog], AIESEC. http://aiesec.org/ value-purpose-driven-leaders

Hahn, T., Pinkse, J., Preuss, L. \& F. Figge (2015). 'Tensions in corporate sustainability: Towards an integrative framework' in Journal of Business Ethics 127(2):297-316.

Hersey, P. \& K.H. Blanchard (1969). 'Life-cycle theory of leadership' in Training and Development Journal 23(5):26-34.

Herzberg, F., Mausner, B. \& B.B. Snyderman (1959). The Motivation to Work. New York, N.Y.: Wiley.

Hill, L.A., Brandeau, G., Truelove, E. \& K, Linebeck (2015). 'The capabilities your organisation needs to sustain innovation' in Harvard Business Review https://hbr.org/2015/01/the-capabilities-your-organization-needs-to-sustaininnovation

Honeyman, R. (2014). The B Corp Handbook: How to Use Business as a Force for Good. San Francisco, Ca.: Berrett-Koehler Publishers, Inc.

House, R.J. (1977). 'A 1976 theory of charismatic leadership' in Hunt, J.G. \& Larson, L.L. (eds.). Leadership: The Cutting Edge. Pp. 189-207. Carbondale: Southern Illinois University Press.

EY Beacon Institute (2018). How Can Purpose Reveal à Path Through Disruption? Mapping the journey from rhetoric to reality. https://www.ey.com/Publication/vwLU Assets/ey-how-can-purpose-reveal-a-path-through-uncertainty/\$File/ey-how-canpurpose-reveal-a-path-through-uncertainty.pdf

Howie, G. (1968). Aristotle, London: Collier-Macmillan Ltd.

Hutchison, L.J. (2011). A Valued Garden: Determining an Appropriate Mission for the Founders Memorial Garden. Master's Thesis, The University of Texas. https://getd. libs.uga.edu/pdfs/hutchison_lindsey_j_201105_mla.pdf

Jacobs, G.A. \& G.J. Longbotham (2011). 'The impact of spirituality on the formation of a leader's purpose' in Journal of Management, Spirituality and Religion 8(1):69-91.

Kahane, A. (2004). Solving Tough Problems: An Open Way of Talking, Listening and Creating New Realities. San Francisco: Berrett-Koehler Publishers.

Kempster, S., Jackson, B. \& M. Conroy (2011). 'Leadership as purpose: Exploring the role of purpose in leadership practice' in Leadership 7(3):317-334,

Kolzow, D.R. (2014). Leading From Within: Building Organisational Leadership Capacity.International Economic Development Council. https://www.iedconline.org/ clientuploads/Downloads/edrp/Leading_from_Within.pdf

Kotter, J.P. (1996). Leading Change. Boston: Harvard Business School Press.

Ladkin, D. (2008). 'Leading beautifully: How mastery, congruence and purpose create the aesthetic of embodied leadership practice' in The Leadership Quarterly 19(1):31-41.

Lin, C.P. (2010). 'Modeling Corporate Citizenship, Organizational Trust, and Work Engagement Based on Attachment Theory' in J Bus Ethics:(94(4):517-531

MacIntyre, A. (2004). 'Virtue ethics' in Genster, H.J., Spurgin, E.W. \& Swindal, J. C. (eds) Ethics: Contemporary Readings, pp 249-256. London: Routledge. 
Malbašić, I., Rey, C. \& N. Posarić (2018). 'Congruence between personal and organisational mission: The role of balanced organisational values' in Ekonomska Misao i Praksa 2:545-563.

Marimon, F., Mas-Machuca, M. \& C. Rey (2016). 'Assessing the internalisation of themission' in Industrial Management and Data Systems 116(1):170-187.

Marques, J. \& S. Dhiman (2017). Leadership Today. Practices for Personal and Professional Performance. Switzerland: Springer International Publishing.

Mayfield, W. (2013). 'The four qualities that define purposeful leaders' in HVACR Management Magazine. http://www.hvacrbusiness.com/4-characteristics-purposeful leadership.html

McClelland, D.C. (1965). 'Achievement motivation can be developed' in Harvard Business Review 43:7-16.

McGregor, D. (1960). The Human Side of Enterprise. New York, N.Y.: McGraw-Hill

Merriam-Webster (2020). Merriam-Webster Dictionary and Thesaurus. Springfield, Mass.: Mariam-Webster, Inc.

Murray, K. (2017). People with Purpose. How Great Leaders Use Purpose to Build Thriving Organisations, London: Kogan Page Ltd.

Northouse, P.G. (2019). Leadership, 2nd ed. London: SAGE.

O'Reilly, C.A. \& M.L. Tushman (2013). 'Organisational ambidexterity: Past, present, future' in Academy of Management Perspectives 27(4):324-338.

Pye, A. (2005). 'Leadership and organizing: Sense-making in action' in Leadership 1(1):31-49.

Quinn, R.E. \& A.V. Thakor (2018). 'Creating a Purpose-Driven Organisation' in Harvard Business Review https://hbr.org/2018/07/creating-a-purpose-driven-organisation

Rafferty, A.E. \& M.A. Griffin (2004). 'Dimensions of transformational leadership: Conceptual and empirical extensions' in The Leadership Quarterly 15(3):329-354.

Ramsey, R.D. (2003). 'Do you need your own mission statement?' in Supervision 64(2):12-14.

Rost, J.C. (1991). Leadership for the 21st Century. New York, N.Y: Praeger.

Rousmaniere, D. (2015). 'What everyone should know about office politics' in Harvard Business Review https://hbr.org/2015/02/what-everyone-should-know-about-officepolitics.

Schein, E.H. (2010). Organisational Culture and Leadership, 4th ed. San Francisco CA: John Wiley \& Sons, Inc.

Shamir, B., House, R.J. \& M.B. Arthur (1993). 'The motivational effects of charismatic leadership: A self-concept-based theory' in Organisation Science 4(4):577-594.

Smircich, L. \& G. Morgan, G. (1982). 'Leadership: The management of meaning' in Journal of Applied Behavioral Science 18(3):257-273.

Steger, M.F., Dik, B.J. \& Duffy, R.D. (2012). 'Measuring meaningful work: The work and meaning inventory (WAMI' in Journal of Career Assessment 20(3):322-337.

Steger, M.F. Littman-Ovadia, H., Miller, M., Menger, L. \& S. Rothmann (2013). 'Engaging in work even when it is meaningless: Positive affective disposition and meaningful work interact in relation to work engagement' in Journal of Career Assessment 21(2):348-361.

Stogdill, R.M. (1948). 'Personal factors associated with leadership: A survey of the literature' inJournal of Psychology 25(1):35-71.

Strange, J.M. \& M.D. Mumford (2002). 'The origins of vision' in The Leadership Quarterly 13(4):343-377.

Taiwo, A.A., Lawal, F.A. \& M.E. Agwu (2016). 'Vision and mission in organisation: Myth or heuristic device?' in International Journal of Business and Management 4(3):127-134. 
Vol. 7, No. $3 \quad$ Vercueil \& Nicolaides: Considering the Issue of Purpose in Leadership...

Treviño, L.K. \& K.A. Nelson (2017). Managing Business Ethics: Straight Talk About How to Do It Right, 7th ed. Hoboken, NJ: John Wiley \& Sons, Inc.

Venus, M., Stam, D. \& D. van Knippenberg (2013). 'Leader emotion as a catalyst of effective leader communication of visions, value-laden messages, and goals' in Organisational Behavior and Human Decision Processes 122(1):53-68.

Western, S. (2019). Leadership: A Critical Text, 3rd ed, London: SAGE.

Wilson, C. (2015). Designing the Purposeful Organisation: How to Inspire Business Performance Beyond Boundaries. London: Kogan Page.

Yukl, G.A. (2013). Leadership in Organisations, 8th ed, NJ: Pearson.

Zimmer, C. (2011). 'The brain: Memories are crucial for looking into the future' in Discover.http://discovermagazine.com/2011/apr/24-the-brain-memoriescruciallooking-into-future 